\section{ENDODONTICS WITH ONE CLICK}

The Optima MX INT system from Bien-Air provides a new approach to endodontic work. The 'click and work' philosophy enables you to start treatment in a single click.

The Optima MX has an impressively simple navigation system, allowing you to change the treatment settings in just a few clicks. You can perform root treatments safely with a significantly reduced risk of instrument breakage due to the auto reverse function.

The Optima MX INT's intuitive display converts your air-driven system to an upgraded electric operation, so for example NiTi endodontics can be covered with a 1:1 contra-angled handpiece. Most other procedures are covered with just two contra-angles (1:1 and 1:5) due to the unique performance of the motor and control systems.

The system can also be quickly and easily tailored to your individual requirements.

\section{Reader response number 63}

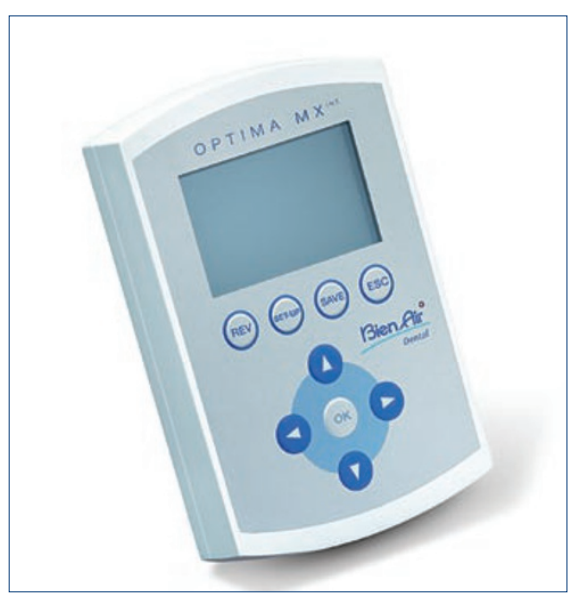

\section{TRIPLE ENZYME CLEANER}

Nusonics MED is a triple enzyme bacteriostatic cleaner designed for use in washer-disinfectors. It is $\mathrm{pH}$ neutral, non-corrosive, biodegradable, residue free, non-foaming and triple enzyme.

Nusonics MED from Blackwell Supplies is available in a four litre container and fulfils all the requirements necessary to make it a highly effective instrument decontamination product.

Reader response number 66

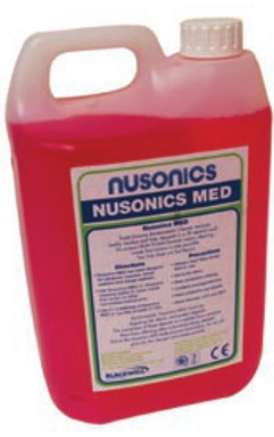

natural s-shape thus preventing the discs from being put under pressure. The hips are kept at the optimum angle of $45^{\circ}$ to the spine so back and thigh muscles are at their most relaxed. Each Bambach Saddle Seat is fully adjustable to create a bespoke stool for each individual.

The Bambach Saddle Seat is endorsed by the Australian Physiotherapy Association and a 30-day free trial in your own practice is available.

Reader response number 64

\section{DISPOSABLE SYRINGE TIPS}

Guaranteeing clean, dry air the SaniTip system promotes total patient confidence in the practice's cross infection control procedures and trouble-free restorations.

The Sani-Tip's disposable tips are easy to use and can be bent up to an angle of $90^{\circ}$, still maintaining optimum performance.

It only takes a few minutes to adapt Sani-Tips to your chair and your Dentsply representative will be able to do this for you for free at a time convenient for you.

Sani-Tips can be relied upon to deliver water and dry air predictably. For a limited time only, Dentsply is offering dental professionals 200 Sani-Tips for free when they buy a 1,500 bulk bag. Reader response number 65

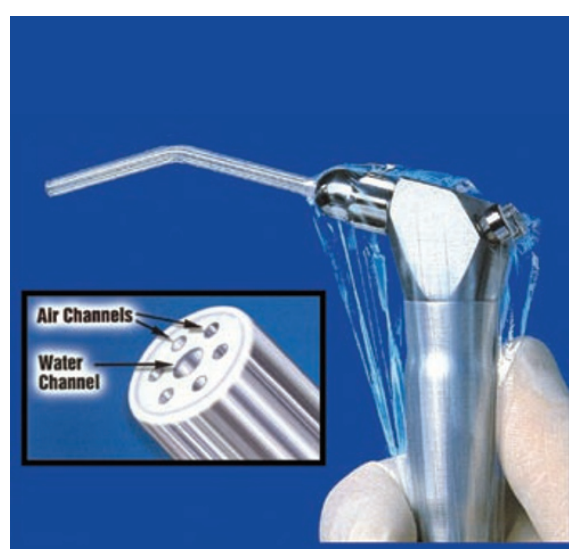

\section{A SUPER OXYGENISED SOLUTION}

One Saniswiss biosanitiser wipe will clean, disinfect and decontaminate in one, covering up to $4 \mathrm{~m}^{2}$ in one wipe.

Available through Bambach, Saniswiss wipes are made from biodegradable paper and due to their large size, cover an area over four times greater than other wipes on the market.

Saniswiss biosanitiser does not contain alcohol, aldehydes or other chemicals found in most disinfectants, which are known health hazards. Instead it converts germs using a unique patented super oxygenised water solution. This product in effect 'digests' the virus, bacteria or fungi leaving no residue so the surface will be cleaner than ever before.

Being a water product, Saniswiss is in contact with the surface for longer - it will not evaporate like alcohol meaning that it is even more effective at killing germs.

Reader response number 67 